Pawel Kowalski

\title{
GENERAL ECONOMIC MAPS IN SCHOOL ATLASES AT THE BEGINNING OF I HE 20TH CENTURY
}

Economic maps were generally introduced into school atlases as late as the beginning of this century. whereas the first economic maps enclosed in school atlases were published already in 1792. They were comprised by a two-volume atlas of J. F. Bertuch's printing house "Industrie Comptoir" from Weimar entitled A.C. Gaspar' Neuer Mothodischer Schulatlas (A. 1). The first volume of that atlas was entirely composed of maps of economic contents. What was new in Bertuch's atlas was information on the economy of the particular countries rendered by means of maps, not the accompanying texts, as it happened in other 18th-century maps.

Next economic maps in school atlases are to be found as late as the second part of the 1840s. however, till the end of the previous century they were rather rare in atlases meant for schools giving general education. In the $1850 \mathrm{~s}$ economic maps appear also in atlitas for special schools, training merchants and manufacturers. Most often, however, those were maps of particular branches of economy: chiefly industry and commerce.

Economic maps for atlases meant for schools giving general education were introduced most early in Russia. The first atlas containing economic maps, including a general economic map ${ }^{1}$ of European Russia was V'seobshchij atlas dla prepodavania po novomu sposobu geografil by $\mathrm{N}$. Kirov published in 1846 (A.2). It gave rise in Russian school atlas cartography to a series of the home country's general economic maps ("country" being the publication place of an atlas). They are to be found in atlasses by A. Ilyin's publishing house in the last three decades of the previous century (A.3).

1 The general economic maps discussed in the article do not fully comply with the contemporary concept, yet if they show at least two sectors of economy (for example, agriculture and some sectors of industry, or industry and some crops) they may be regarded as such. 
On the other hand, the 20th-century atlases by A. Ilyin's publishing house and by other Russian publishing firms would not include general economic maps but morely sets of analytic economic maps of Russia characterizing chiefly agriculture and industry.

In the European countries economic maps in school atlases appeared later than in Russia. Most early, already in 1851, they are to be found in an English atlas by S. Clark-A. Petermann Maps Illustrative... (A.4), then in 1853 in School Atlas of Physical and Commercial Geography by E. Hughes (A.5). Over the succeeding decades economic maps were not included in English school atlases. They appear as late as the turn of the 1880 s mainly in specialized atlases for commercial and economic schools.

In France, however, economic maps for school atlases for both schools giving general education and vocational ones were introduced by $\mathrm{E}$. Belin publishing house in the middle of the 1880 s (A.6). In school atlises by other French publishing houses economic maps appeared towards the end of the 1890s or at he beginning of the 20th century.

Hummel's Schul-Atlas in 1887 was first among German nineteenthcentury school atlases to enclose economic maps (A.7); it was followed in 1895 by Diercke Schulatlas (A.8).

In other European countres economic maps were introduced into school atlases as late as the beginning of this century. In the Austro-Hungarian Monarchy they were published, for instance, by Kozenn's atlas (A.9) in 1906, in Switzerland - in 1910 by Atlas für Schweizerische Mittelschulen.

Most of the economic maps included in atlases for schools giving general education, despite their limited range of the contents, may be regarded as general economic maps.

Due to differentiation of the range of the contents, different approach to those contents as well as the specific character of the applied methods of presentation, discussion of economic maps grouped according to the size of the territories presented in maps was regarded as most proper. Therefore maps of countries, maps of continents and maps of the world will be discussed separately.

The school atlases published at the beginning of this century would usually represent the territory of the home country in two or three maps whose contents were composed of the particular branches of national economy. One of the maps would as a rule present agriculture and industry, the other agriculture. There were also atlases of a more detailed approach to the economic characteristics of the home country adding thus to the number of maps that presented all major branches of industry, crops, types of stock-breeding, even transport. Table 1 illustrates the approach to economic issues on maps of the home country. It shows, among other things, which of the school atlases included in the spe- 
cification comprised general economic maps of the home country and two other selected exemplary countries France and Great Britain, and which of them comprised maps of particular sectors of economy or maps of sectors of industry. Table 1 also presents which of the sectors and kinds of industry that existed before World War I were found on the above-mentioned types of economic maps. The table also includes an atlas from the end of the 19th century - Diercke Schul-Atlas published in 1895 (A.9) for the sake of comparison with the former ones.

General economic maps were included only in Austrian atlases: Kozenns Geographischer Atlas, F. Heiderich, W. Schmidt, 1906 (A.12) and Tramplers Geographischer Mittelschulatlas, 1913 (A.20) (Table 1). They did not, however, present economy of the whole country but that of particular provinces of the Austro-Hungarian Monarchy and were made in relatively big scales $(1: 2,500,000,1: 3,000,000,1: 5,000,000)$.

The general economic maps included in the two Austrian atlases differ from each other in respect of both graphic expression and minuteness of detail of the thematic approach. This particularly pertains to the representation of industry. In Kozenn's atlas five branches of industry marked on the map with "line renges" have been distinguished. Whereas breweries and electric power stations have been presented by means of "point symbols".

Despite a relatively small number of details those maps are not clear, which results from accumulation of too many undifferentiated "range lines" that prevail in the map's graphic image.

The graphic appearance of the general economic maps in Tramplers Geographischer Mittelschulatlas are different, particular kinds of industry having been presented by means of "point symbols" and "names underlining of localities with lines of different colours". ${ }^{2}$ Compared with Kozenn's atlas those maps are much more detailed and their content range is much broader. For example, 22 kinds and branches of industry have been distinguished whereas in Kozenn's atlas there were only 6 of them (Table 1). Moreover, centres of mining of mineral resources have been marked with "point symbols", which is not to be found in Kozenn's atlas.

On the general economic maps in the two Austrian atlases agriculture was characterized by sub-division into five types of agricultural areas. Four of them were distinguished on the basis of prevailing cereals and the fifth one included mountain areas. In Tramplers Geographicher Mittelschulatlas there was an additional presentation of distribution of the particular crops and stock-breading varieties, the descriptive range method having been applied for that purpose.

2 "Underlining of names" as a method of emphasizing certain properties (features) of objects E. Arnberger (1966) calls the "underline symbol method" (Die Unterstreichungssignaturen). 
䒕

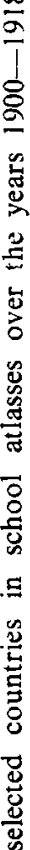

范

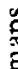

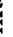

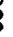

ㅁำ

is

息

몯

:

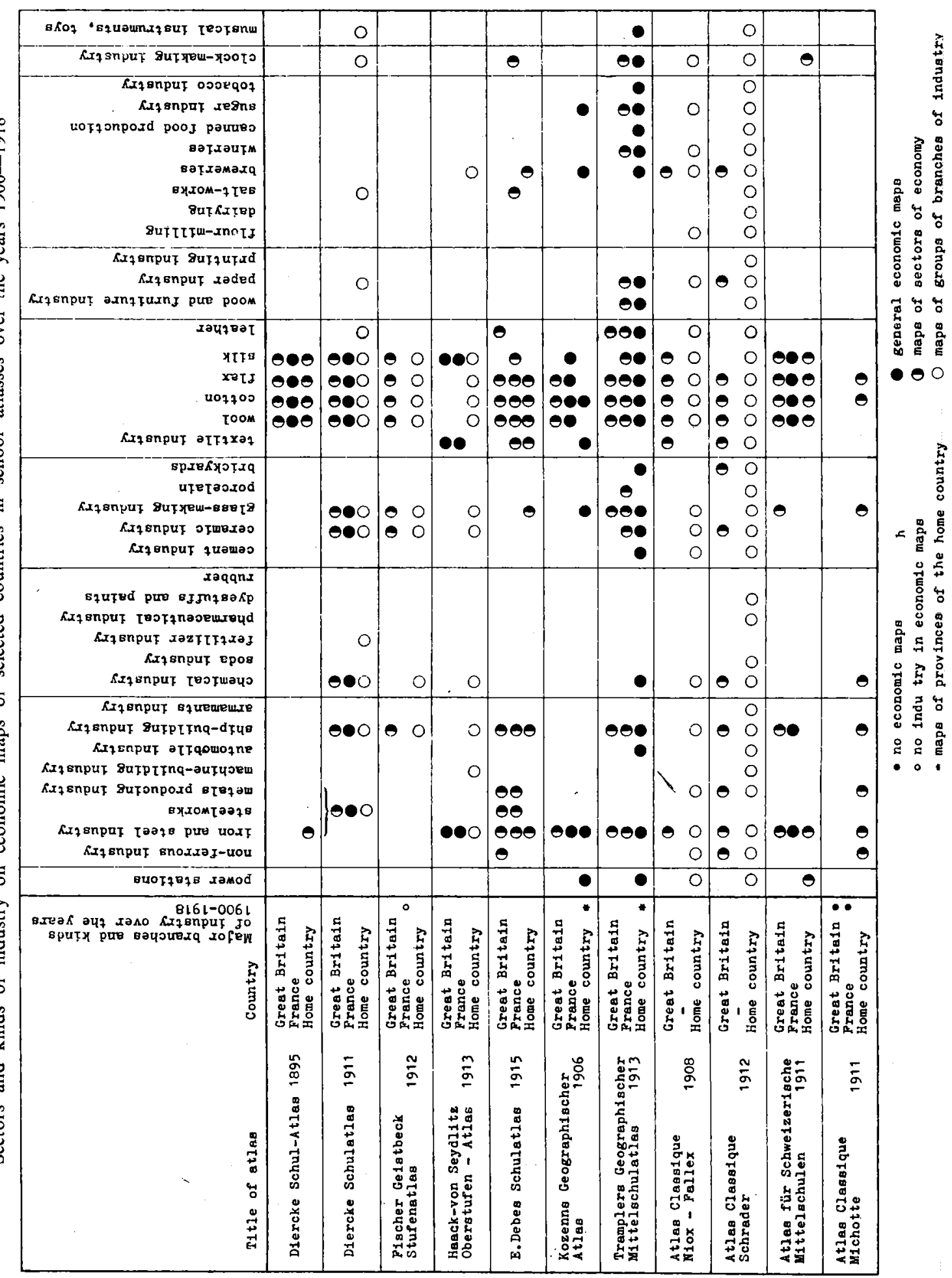


Economic characteristics of other countries - beyond the home country - in most of the school atlases published at that time were presented on general economic maps. It was only Germany and Great Britain, that is highly developed countries, for which as a rule two or three maps of the particular sectors of economy were included. Whereas another highly developed country--France. just like other countries of secondary importance, in most of the school atlases was presented in one general economic map. This is why it is France, Great Britain and the home country that have been chosen in Table 1 as exemplary countries in order to illustrate the degree of minuteness of detail in the approach to industry in general economic maps.

Economic maps of other countres, apart from the home country, were elaborated in scales much smaller than those of the main general maps. In case of European countries those scales were two or three times smaller. for non-European countries they were even five times smaller.

In atlases published over the time from the beginning of the 20th century to World War I several types of general economic maps can be distinguished, the range of the contents and the applied methods of presentation having been accepted as the criteria of such a sub-division:

Type 1. General economic maps in atlases for school giving general education were characteristic of the rang' method being applied most often. Maps of this type, alongside with economic contents, were additionally provided with yearly isotherms or isotherms of January and July. They are to be found in some German and Austrian atlases published before World War 1. The examples are the folowing atlases: Kozenns Goographischer Atlas für Mittelschulen, 1906 (A.12), Diercke Schulatlas, (A:10), Haack-von Seydlitz Oberstufen Atlas, 1913 (A.19). Isotherms, a charcteristic element of the contents of most economic maps in school atlases at the beginning of the 20th century, were removed from those maps before World War $1^{3}$ For instance. the new edition Diercke Schulatlas from 1911 (A.16) does not include isotherms on economic maps any more.

The essential contents of the maps of the type under discussion were most often made up of distribution of sectors or kinds of industry characteristic of a given country, mineral resources and some crops. In case of countries of secondary importance the contents of maps were more limited.

The most comprehensive economic contents is comprised by the maps included in: Haack-von Seydlitz Oberstufen Atlas (A.19), Diercke Schulatlas (A 16) and Atlas für Schie'zerische Mittelschulen (A.15). As results from the analysis of general economic maps of Type 1. industry, for instance

${ }^{3}$ Separate general econ mic maps with isotherms are to be found still in the time between the wars, e.g. in the French atlas Atlas Classiciue, F. Schrader, E. Galloudee, 1936 (A 23); this results, however, from including maps from former issues without alterations. 
on maps of France, was approached in the most detailed way in Diercke Schulatlas (A.16). On the other hand, the least number of industries was presented in Haack-von Seydlitz Oberstufen Atlas (A.19), which in turn approached agriculture, stock-breeding and fishery in a most comprehensive manner in terms of the number of differentiations. The big test amount of mineral resources was shown by Atlas für Schweizerische Mittelschulen (A.15). Table 1 presents a comparison of the kinds and branches of industry differentiated in general economic maps in the above discussed atlases. The table also illustrates a considerable span of minuteness of detail while approaching industry in general economic maps and in maps meant for particular sectors of economy.

The choice of cartographic presentation methods also contributes to such a big differentiation. In the maps most characteristic of the discussed Type 1, it was the range method that was most often made use of, the symbol method was by far not so frequent. Among the methods of graphic marking of ranges, lines, colour surfaces, patterns prevailed within this group of maps; the "method of descriptive ranges" was applied merely for marking of stock-breeding and some of the crops. In atlases in which the "range method" was chiefly applied for characterization of industry in general economic maps, a considerably more limited content scope is to be observed than in atlases that applied for that purpose both the "range method" and the "point symbol method". For example, Kozenn's and Haack-Seydlitz's atlases should be classified into the former group, while that of Diercke's - into the latter.

The hitherto discussed Type 1 was the most characteristic type of general economic maps in school atlases over the first decade of this century. Despite their small scales, those maps were clear and easy to read for the range of their contents was limited down to presentation of raw materials, industry, crops and stock-breeding disregarding the land use forms.

Type 2. The general economic maps included in school atlases by E. Debes (A.21, A.22) since 1914 have been an example of a slightly different choice of the contents. The range of "culture areas" (Kulturland) determined on the basis of criteria subjected to the specific character of the agriculture of a given country or region constituted a new element in those maps. Against this background the occurrence of mineral resources was shown chiefly by means of "letter symbols", every now and then by means of the range. The main industrial centre (Hauptindustrieorte) and centres of smaller industry (Gewerbtätige Orte) were marked by means of "point symbols". Besides,' centres of metallurgical and textile industry were distinguished, too.

Type 3. The general economic maps in French atlases, e.g. Atlas Classique G. Niox, M. Fallex, 1908 (A.14), Atlas 'Classique F. Schrader, L. Gallouedec, 1912 (A.17), as well as the abridged version of the great 
atlas by Vidal de la Blache (A.9) for school and public use Atlas Classique Vidal-Lablache, 1907 (A.13). The general economic maps in those atlases were characteristic of a specific graphic expression. It resulted chiefly from the method of inscriptions denoting the "ranges of descriptive range", "patch range" and "descriptive symbols" The map was provided with the names of the kinds of production, crops and stock-breeding characteristic of a given country, every now arid then against a background of "patch ranges". Thus most of those maps were unclear, which resulted from inscriptions having been accumulated to excess. Such a method of cartographic presentation did not help to remember through associations. It should be emphasized that the maps elaborated by M. Fallex were characteristic of a purposefully simplified, limited range of the contents, which is partly illustrated by Table 1 .

Type 4. The maps elaborated by $E$. Friedrich are the examples of general economic maps of the fourth type. Their content range and presentation methods were characteristic of German school commercial atlases over the opening two decades of this century. They would shown vecurrence of crops, stock-breeding and mineral resources, whose names were attached to the map. The Velhagen Klasing publishing house introduced this type of maps also into the atlas for general education schools: Stufenatlas für höhere Lehranstalten, H. Fischer, M. Geitsbeck, 1912 (A.18).

General economic maps of continents were included only in very few school atlases over the first decade of the 20th century. They are to be found in the fore-mentioned Stufenatlas fïr Lahranstalten, 1912 (A.18), in Tramplers Geographischer Mittelschulatlas, 1913 (A.20) and the school atlases by Debes (A.21, A.22). In other atlases of that time it was only distribution of mineral resources that was shown in maps of continents on very small scales.

The general economic maps of continents in Stufenatlas für höhere Lehranstalten were elaborated by E. Friedrich and would come also from atlases for commercial schools published by Velhagen \& Klasing. The characteristic feature of those maps was their considerably large scale equal to that of general geographic maps with which the economic maps were paired off. The range of the contents and the choice of graphic methods of presentation were also characteristic of this type of maps. The aim was the presentation of spatial distribution of mineral resources, crops, stock-breeding, fishery and the area's transport conditions (E. Friedrich, 1901 p. 20). Such maps entitled Produkte und Verkehrslinien had been elaborated for all continents save Europe. As for Europe maps of particular sectors of economy - industry, agriculture, transportation of goods and people - were included.

On general economic maps of continents, except for Europe, distribution of mineral resources, crops and stock-breeding was presented by means of the "range method", all possible ways of graphic presentation of the 
method having been applied at that. Transportation network over the areas of continents and oceans was presented by means of line symbols. Tte detailed character of those maps caused - despite their large scale-their over-abundance of graphic symbols and thus difficulties in reading them, especially by pupils.

The general economic map of Europe, scale $1: 20,000,000$, included in both atlases by E. Debes is also worth noting. Maps of other continents in those atlases had been elaborated on the scale of $1: 90,000,000$, i.e. twice smaller than that of the major general maps. On the map of Europe, "culture areas" (Kulturland), areas of "particular income" and "great areas of forests, meadows and barren land" were distinguished by means of the "colour range method". Distribution of major crops, varieties of stock-breeding, some branches and kinds of industry were marked by means of the "range method". Too big number of names of raw materials, varieties of crops and stock-breeding, as well as branches of industry comprised by the map caused its readability and clarity to be decreased.

The maps of continents in Tramplers Geographischen Mittelschulatlas (A.20) had been elaborated only for Asia and Africa on a very small scale of $1: 1000,000,000$. On those maps, entitled Wirtschaftsverhältnisse. "forms of economy" had been distinguished according to E. Hahn's (1892) classification. Against this background the occurrence of mineral raw materials had been presented by means of "geometrical symbols", as well as stock-breeding, which was shown by means of "descriptive and line range".

Synthetic economic maps of the world, elaborated on the basis of E. Hahn's classification, would be included in German, Austrian and Swiss atlases. Some publishers did not mark in those maps all categories, e.g. Diercke Schulatlas (A.16) did not take into account industry and mining, whereas Kozenns Geographischer Atlas (A.12) was restricted to presentation of only three categories: crops, stock-breeding, hunting and fishery.

While summing up the development of general economis maps in school atlases over the period between the end of the lyth century up till World War I one should point out the following facts:

- general economic maps, just like other thematic maps in the line of social-economic geography, were only complementary ones (Nebenkarten),

- scales of those maps were as a rule much smaller than those of the main general maps,

- general economic maps of the home country were included only in Austrian atlasses,

-.- economic characteristics of other countries, except the home country, in most of the school atlasses of that time were presented on general economic maps, 
- the range of the contents of those maps was limited down to presentation of sheer economic elements (most often industry, crops and stock-breeding varieties, every now and then also raw materials),

- the characteristic element of the contents of contemporary general economic maps - land use forms (arable land, grassland, forests, barren lands, etc.) were not presented on those maps,

- the "range method" was the most often applied method of presentation of economic problem; the "symbol method" was made use of much less frequently,

- economic maps of the world were made synthetically on the basis of E. Hahn's classification "forms of economy".

\section{REFERENCES}

Fick, K. E., 1971, "Die Kartographische Darstellung wirtschaftsgeographische Sachverhalte im 18 Jahrhundert", Geographische Zeitschrift, Bd. 59, H. 2, s. 131-139.

Friedrich, E., 1901, Die Anwendung der kartographischen Darstellungsmittel auf wirtschaftsgengraphischen Karten, Druck von C. Schönert, Leipzig.

H a h n, E., 1892, "Die Wirtschaftsformen der Erde", Petermanns Geogr. Mitt., 38, s. 8-12. Oppel, A., 1891, "Über Wirtschaftsgeographie und wirtschaftsgeographische Karten", Deutsche Geographische Blätter, Bd. XIV, s. 43-64.

P r e o b a zhe n s ky, A. I., 1953, Ruskije ekonomicheskije karty i atlasy, Izd. Geografgiz, Moskwa.

Robins o n, A. H., 1982, Early thematic mapping in the history of cartography, The University of Chicago Press., Chicago and London.

\section{ATLASES}

A.1 A. C. Gaspari Neuer methodischer Schul-Atlas..., J. F. Bertuch, Weimar 1792, Verlage des Industrie Comptoirs.

A.2 Vseobshchij atlas dlia prerodovanija po novomu sposobu geografii politicheskoj, etnologicheskoj i fizicheskoj..., N. Kirow, Moskwa 1846.

A.3 Uchebnyj geograficheskij atlas A. Iljina polnovo gimnazicheskoho kursa, A. Iljin, S. Petersburg $1874-1889$, A. Iljin.

A.4 Maps illustrative of the physical, political and historical geography of the British Empire, S. Clark, A. Peterman, National Society for Promoting the Education of the Poor, London 1851.

A.5 A school atlas of physical, political and commercial geography, Edward Houghes, Longman, Brown, Green, and Longmans 1853, London.

A.6 Nouvel atlas de géographie moderne, M. M. Drioux, Ch. Leroy, Paris 1886, Libraire Classique d'E. Belin.

A.7 Hummel's Schulatlas zum Unterricht in der Erdkunde, A. Hummel, Leipzig 1889, Körner Dietrich.

A.8 Atlas giniral, P. Vidal de la Blache, Paris 1894, A. Colin C'ie.

A.9 Diercke Schul-Atlas für höhere Lehranstalten, C. Dircke, E. Gaebler, Braunschweig 1895, Verlag G. Westermann.

A.10 Diercke Schul-Atlas für höhere Lehranstalten, C. Diercke, E. Gaebler, Braunschweig 1900 , George Westermann.

A.11 Atlas für höhere Lehranstalten, R. Lehmann, A. Scobel, Bielefeld und Leipzig 1903, Verlag von Velhagen Klasing. 
A.12 Kozenns Geographischer Atlas für Mittelschulen..., F. Heiderich, W. Schmidt, Wien 1906, Ed. Hölzel.

A.13 Atlas Classique I'idal de la Blache ... Histoire et géographie..., Paris 1907, A. Colin.

A.14 Atlas Classique, G. Niox. M. Fallex, E. Darsy, Paris 1908, Librairie Ch. Delagrave.

A.15 Atlas für Schwoizerische Mittelschulen. Konferenz der kantonalen Erziehungsdirektoren, Zurich 1911, Kart. Winterthur.

A.16 Diercke Schulatlas für höhere Léhranstalten, P. Diercke, Braunschweig und Berlin 1911, George Westermann.

A.17 Atlas Classicue de Geographie Ancienne et Moderne, F. Schrader, L. Gallouedec, Paris 1912, Librairie Hachette et C'is.

A.18 Stufenatlas für höhere Lehranstalten, H. Fischer, M. Geistbeck, Bielefeld und Leipzig 1912, Verlag von Velhagene Klasing.

A.19 Haack-von Seydlitz Oberstufen-Atlas für höhere Lehranstalten, H. Haack, Gotha 1913, Perthes.

A.20 Tramplers Geographischer Mittelschulatlas, Wien 1913, Verlag der K. K. Hof- und Staatsdruckerei.

A.21 E. Debes Schulatlas fïr die unteren und mittleren Unterrichtsstufen. Leipzig 1914, Verlag von H. Wagner u. E. Debes.

A.22 E. Debes Schulatlas für die obere Unterrichtsstufe, A. Kirchoff, H. Kropatscheck, Leipzig 1915, Verlag von H. Wagner u. E. Debes.

A.23 Atlas Classique, F. Schrader, L. Gallouédec, Paris 1931. Librairie Hachette. 